\title{
The Role of the Small Bowel in Unintentional Weight Loss after Treatment of Upper Gastrointestinal Cancers
}

\author{
Babak Dehestani and Carel W le Roux * \\ Diabetes Complications Research Centre, University College Dublin, D04 HV52 Dublin, Ireland \\ * Correspondence: carel.leroux@ucd.ie
}

Received: 8 June 2019; Accepted: 28 June 2019; Published: 28 June 2019

check for updates

\begin{abstract}
Upper gastrointestinal (GI) cancers are responsible for significant mortality and morbidity worldwide. To date, most of the studies focused on the treatments' efficacy and post-treatment survival rate. As treatments improve, more patients survive long term, and thus the accompanying complications including unintentional weight loss are becoming more important. Unintentional weight loss is defined as $>5 \%$ of body weight loss within $6-12$ months. Malignancies, particularly GI cancers, are diagnosed in approximately $25 \%$ of patients who present with unintentional weight loss. Whereas some recent studies discuss pathophysiological mechanisms and new promising therapies of cancer cachexia, there is a lack of studies regarding the underlying mechanism of unintentional weight loss in patients who are tumor free and where cancer cachexia has been excluded. The small bowel is a central hub in metabolic regulation, energy homeostasis, and body weight control throughout the microbiota-gut-brain axis. In this narrative review article, the authors discussed the impacts of upper GI cancers' treatment modalities on the small bowel which may lead to unintentional weight loss and some new promising therapeutic agents to treat unintentional weight loss in long term survivors after upper GI operations with curative intent.
\end{abstract}

Keywords: gastrointestinal; cancer; small bowl; unintentional; weight loss

\section{Introduction}

Upper gastrointestinal (GI) cancers include oesophageal, stomach, duodenal, liver, gallbladder, biliary tract, ampulla of Vater, and pancreatic cancers. These cancers are responsible for significant mortality and morbidity worldwide [1]. According to the GLOBOCAN 2018, cancers of the stomach, liver and esophagus together represent $13.5 \%$ of all cancers in 2018, but are responsible for $26.2 \%$ of the mortality due to cancer [1].

The GI tract is an integrated system with signaling between organs, tissues and cells. Unsurprisingly, the most common site of distant metastasis of upper GI cancers is the liver [2-6]. Treatment options for upper GI cancers include surgery, chemotherapy, radiation therapy, chemoradiation therapy, targeted therapy, and surgical/endoscopic palliative interventions [7-10]. Consequently, defining a therapeutic plan for each patient requires a multidisciplinary approach including gastroenterologists, pathologists, GI surgeons, oncologists, radiologists, radiation oncologists, general practitioners, dietitians, psychiatrists/psychologists and social workers [7,11,12].

To date, most of the studies focused on the efficacy and post-treatment survival rate. As treatments improve, more patients survive long term, and thus understanding altered gut-brain signaling pathway and unintentional weight loss are becoming more important.

Unintentional weight loss is defined as $>5 \%$ of body weight loss within $6-12$ months. Malignancies, particularly GI cancers, are diagnosed in approximately $25 \%$ of patients who present with unintentional 
weight loss [13-15]. Moreover, the highest frequency of weight loss is seen among the patients with pancreatic or gastric cancer [16,17]. Although the cancer in itself can cause weight loss, the treatment which may include surgical rearrangement of the small intestine may also contribute. If unintentional weight loss after surgery with curative intent is between 10 and 30\% from starting weight, then long term morbidity and mortality increase even in those in remission of cancer [18-22].

Unintentional weight loss can be considered as both a sign and a complication of cancers and their treatment. Some recent studies discussed pathophysiological mechanisms and new promising therapies for cancer cachexia which is characterized by the ongoing loss of skeletal muscle mass with or without loss of fat mass $[17,23-26]$. However, there is a lack of studies regarding the underlying mechanism of unintentional weight loss in patients who are tumor free and where cancer cachexia has been excluded.

\section{Role of the Small Intestine in the Gut-Brain Axis}

The cycle of repetitive episodes of hunger and satiation depends on harmonized bidirectional communication between the subcortical areas of the central nervous system (CNS) and GI system via endocrine, neurocrine and paracrine interactions [27]. The gut-brain axis (GBA) includes the central nervous system (CNS), both brain and spinal cord, the autonomic nervous system (ANS), the enteric nervous system (ENS) and the hypothalamic pituitary adrenal (HPA) axis. Gut-microbiota have also emerged as having important roles in the microbiota-gut-brain axis [28-31].

Satiety gut hormones, such as glucagon-like-peptide 1 (GLP-1), Peptide YY (PYY) and oxyntomodulin (OXM) are released from L-cells when food comes into contact with the small bowel mucosa [32]. L-cells are present from duodenum to the rectum, however, they are most abundant in the ileum and colon. The early response of duodenal L-cells in releasing satiety hormones may be enhanced by neural regulation and intraluminal short-chain fatty acids (SCFAs), bile acids and amino acids [32-35].

Bile acids are now considered major signaling molecules as they activate Farnesoid $\mathrm{X}$ receptor (FXR) and G protein-coupled bile acid receptor 5 (TGR5). This leads to stimulating secretion of GLP-1 and regulates glucose and energy homeostasis, lipid metabolism, and gut microbiota [36-39]. Visceral signaling of satiation is further enhanced by small bowel gut microbiota. Short-chain fatty acids (SCFAs) including propionate, butyrate and acetate which are mainly produced via fermentation of dietary fibers by gut microbiota, also increases G-protein mediated secretion of PYY and GLP-1 [39-41]. The small bowel is thus a central hub in metabolic regulation, energy homeostasis, and body weight control.

\section{Impacts of Upper GI Cancers' Treatment Modalities on the Small Bowel}

\subsection{Surgical Procedures}

Operations of the upper GI Cancers including esophagectomy, gastrectomy, Whipple procedure and extended (radical) cholecystectomy involve re-routing the normal GI tract. In particular, the anatomy of the gastroduodenal junction and proximal small intestine are altered. Hence, after these operations, foods rapidly progress into and through the small bowel [42-44]. The mentioned prompt contact of food causes small bowel mucosa adaptation [45-47] and consequently, an increase in absolute number of enteroendocrine L-cells, particularly in the proximal small bowel which finally leads to exaggerated release of gut satiety hormones $[48,49]$. After esophagectomy at 6 weeks and 3 months, body weight decreases and postprandial release of satiety gut hormones (GLP-1) are increased [48]. Another study confirmed that patients after esophagectomy had significant body weight loss at 3, 6, 12 , and 24 months which was associated with increases in postprandial GLP-1 and PYY responses in comparison with the controls [49].

Simultaneously, excess bile enters the small bowel resulting in elevated plasma bile signals [50]. Furthermore, the gut microbiota profile changes after the surgeries which lead to enhancing visceral signals of satiation to the brain reward centers [51-53]. 
In contrast to the satiety gut hormones, Ghrelin as a hunger hormone is mostly secreted by X/A like cells of the fundus of the stomach [54,55], hence, its secretion is initially reduced after curative upper GI cancer surgery. Aside from ghrelin's stimulatory effect on releasing growth hormone (GH) [56,57], it has profound orexigenic and adipogenic characteristics via activating the arcuate nucleus containing neuropeptide $\mathrm{Y}$ (NPY) and agouti-related peptide (AgRP), and inhibiting neurons containing proopiomelanocortin (POMC) in hypothalamus which finally induces feelings of hunger [58,59]. Even though initial ghrelin reduction after upper GI cancer surgery may lead to unintentional weight loss, it cannot fully explain long term unintentional weight loss since ghrelin recovers to baseline levels after $12-24$ months $[60,61]$. Ghrelin analogues have also had limited success in increasing long term food intake and bodyweight $[60,61]$.

Harris et al. showed that loss of taste (hypogeusia) and smell (hyposmia) occurred at nearly $50 \%$ of patients after upper GI cancer surgery. Although it resolves in most patients within 6-12 months, it might impact on changing food preferences, contributing to unintentional weight loss [62]. Taken together, the reduced energy intake and unintentional weight loss after upper GI cancer surgery may be partly explained by the alterations in the gut-brain axis including gut mucosal adaptation; increased visceral signals to the brain; reduced brain reward responses to food; reduced eating behavior; reduced food intake and changed food preferences.

\subsection{Chemotherapy and Radiotherapy}

Chemotherapy (cytotoxic drugs) also target healthy fast-dividing cells including GI tract cells, particularly proliferating enterocytes in the small bowel and colon which can lead to GI mucositis. Consequently, barrier dysfunction and epithelium impairment occurred in GI mucositis [63-65]. Likewise, abdominopelvic radiotherapy adversely affects the normal enterocytes which leads to radiation-induced GI mucositis [66-68]. A wide range of GI symptoms in cancer patients including diarrhea, nausea, vomiting, abdominal pain, malnutrition, bleeding, fatigue and unintentional weight loss may be a consequence of mucositis $[65,67]$.

Gut-microbiota play a significant role in the pathogenesis of mucositis of the GI tract. Montassier et al. found that abundances of Firmicutes and actinobacteria were markedly decreased while there was a considerable increase in abundances of proteobacteria in fecal samples of patients after chemotherapy compared to the samples collected before chemotherapy [65]. The phyla Firmicutes also decreased by $10 \%$ whereas phyla Fusobacterium increased by $3 \%$ after radiation therapy [66]. Bajic et al. suggested chemotherapy causes an integrated dysregulation through the microbiota-gut-brain axis since the most vulnerable cells to the toxic side effects of cytotoxic drugs are GI tract cells, CNS cells and the gut microbiota [64]. However, this does not fully explain the underlying reasons of ongoing unintentional weight loss after chemo/radio therapy-related complications have resolved.

\section{New Promising Therapeutic Agents}

Octreotide, a synthetic somatostatin analogue, acts via somatostatin receptors (SSTRs), a family of G-protein coupled membrane receptors [69,70], to inhibit the satiety gut hormone responses. This may hypothetically lead to stimulation of the brain reward center and increases in food intake and body weight. The inhibition of the satiety gut hormone responses with a somatostatin analogue almost doubled ad libitum food intake [49]. Elliott et al. showed that administration of octreotide in patients after esophagectomy led to attenuation of exaggerated postprandial satiety gut hormone responses which was associated with increased appetitive behavior toward a sweet-fat stimulus [71].

Moreover, patients with progressive cancers or severe dumping syndrome after gastrectomy are often treated for prolonged periods with chronic octreotide [72]. Therefore, octreotide might be considered as a potential therapeutic agent for unintentional weight loss after upper GI cancer surgery. The drug has a well-documented safety profile, is frequently used in patients with cancer and is known to be well-tolerated [72-74]. However, the main side effect of chronic octreotide includes gallstone formation that may result in cholecystitis and pancreatitis $[75,76]$. 
Ghrelin receptor agonists such as Capromorelin and BIM-28163 can increase appetite and food intake which causes weight gain. The administration of Anamorelin-a non-peptide, orally active, selective agonist of the ghrelin/GH secretagogue receptor-demonstrated some clinical benefits in terms of appetite stimulation, improving lean body mass and weight gain in patients with cancer cachexia [77-82]. Therefore, these novel drugs might be some potential therapeutic agents for the patients after treatment with curative intent who are suffering from ongoing unintentional weight loss $[83,84]$.

Decreasing the chances of weight reduction initially right after the cancer surgery or during chemo/radiation therapy may have some beneficial impacts in the long term for these patients. Suitable nutritional support by dietitians postoperatively and considering alternative ways of feeding including parenteral nutrition (PN) or feeding jejunostomy in indicated patients may also attenuate initial weight loss $[82,85,86]$. Probiotics may also have therapeutic effects on chemo/radiation therapy induced GI mucositis by restoring the normal composition of the gut microbiota $[67,87]$.

GABA ( $\gamma$-aminobutyric acid) is the major inhibitory neurotransmitter of the CNS, and NPY/AgRP neurons release GABA to directly inhibit POMC neurons in the hypothalamic arcuate nucleus (ARC) which may result in increased food intake and weight gain $[81,88,89]$. Hence, GABA receptor agonists and GABA reuptake inhibitors might be considered as potential orexigenic agents.

Leptin is an anorexigenic hormone which is secreted by adipocytes and regulates energy expenditure, appetite and body weight. Some animal studies indicate that the administration of leptin receptor antagonists leads to significant increases in food intake and body weight in rodents [90-92]. Hence, these antagonists might be potential therapeutic options for unintentional weight loss.

Alpha-melanocyte-stimulating hormone $(\alpha-\mathrm{MSH})$ is a main product of POMC neurons which exerts its anorexigenic effects via the melanocortin 3 (MC3) and 4 (MC4) receptors in the hypothalamic paraventricular nucleus. Thus, MC4 antagonists such as BL-6020/979 may ameliorate unintentional weight loss and loss of lean body mass in patients after cancer surgeries [93-95].

Fecal microbiota transplantation (FMT) is mainly used for treating recurrent Clostridium difficile infection, inflammatory bowel disease (IBD) and functional gastrointestinal disorders (FGID) [96-99]. However, recent studies demonstrated that FMT may result in altering energy homeostasis, appetite, food preference and body weight due to the new composition of recipient's gut-microbiota after transplantation which is changed by the stool donor's gut microbiota [100,101]. A case study showed that a 32-year-old female developed new-onset obesity after receiving stool from a healthy but overweight donor. Her BMI increased from 26 before FMT to 34.5 at 36 months post-FMT [102]. Animal studies also support transmissible obesity via FMT in mice [103]. Therefore, performing FMT from healthy overweight stool donors may lead to increased food intake and weight gain in patients with unintentional weight loss after cancer treatment.

Treatments for upper GI cancers have improved significantly and more patients are surviving long term. Long term unintentional weight loss may increase morbidity and mortality while also reducing quality of life. The microbiota-gut-brain axis may hold the key to understand and treat unintentional weight loss in long term survivors after upper GI operations with curative intent.

Conflicts of Interest: The authors declare no conflict of interest.

\section{References}

1. Bray, F.; Ferlay, J.; Soerjomataram, I.; Siegel, R.L.; Torre, L.A.; Jemal, A. Global cancer statistics 2018: GLOBOCAN estimates of incidence and mortality worldwide for 36 cancers in 185 countries. CA Cancer J. Clin. 2018, 68, 394-424. [CrossRef] [PubMed]

2. Bitik, B.; Kalpakci, Y.; Altan, E.; Dogan, E.; Altundag, K. Successful treatment of primary duodenal carcinoma with bilateral adrenal metastases with docetaxel-cisplatin-5-fluorouracil regimen. Ann. Oncol. Off. J. Eur. Soc. Med. Oncol. 2009, 20, 394-395. [CrossRef] [PubMed]

3. Riihimaki, M.; Hemminki, A.; Sundquist, K.; Sundquist, J.; Hemminki, K. Metastatic spread in patients with gastric cancer. Oncotarget 2016, 7, 52307-52316. [CrossRef] [PubMed] 
4. Voutsadakis, I.A.; Doumas, S.; Tsapakidis, K.; Papagianni, M.; Papandreou, C.N. Bone and brain metastases from ampullary adenocarcinoma. World J. Gastroenterol. 2009, 15, 2665-2668. [CrossRef] [PubMed]

5. Wu, S.G.; Zhang, W.W.; He, Z.Y.; Sun, J.Y.; Chen, Y.X.; Guo, L. Sites of metastasis and overall survival in esophageal cancer: A population-based study. Cancer Manag. Res. 2017, 9, 781-788. [CrossRef]

6. Yachida, S.; Iacobuzio-Donahue, C.A. The pathology and genetics of metastatic pancreatic cancer. Arch. Pathol. Lab. Med. 2009, 133, 413-422.

7. Boniface, M.M.; Wani, S.B.; Schefter, T.E.; Koo, P.J.; Meguid, C.; Leong, S.; Kaplan, J.B.; Wingrove, L.J.; McCarter, M.D. Multidisciplinary management for esophageal and gastric cancer. Cancer Manag. Res. 2016, 8, 39-44. [CrossRef]

8. Meyer, H.J.; Wilke, H. Treatment strategies in gastric cancer. Dtsch. Arztebl. Int. 2011, 108, 698-705. [CrossRef]

9. Jiang, Y.; Kimchi, E.T.; Montero, A.J.; Staveley-O'Carroll, K.F.; Ajani, J.A. Upper gastrointestinal tumors: Current status and future perspectives. Expert Rev. Anticancer Ther. 2008, 8, 975-991. [CrossRef]

10. Forman, D.; Morris, E.; Eastwood, A.; Kleijnen, J. Guidelines for treatment of upper gastrointestinal cancer. Lancet 2003, 361, 80. [CrossRef]

11. Van Hagen, P.; Spaander, M.C.; van der Gaast, A.; van Rij, C.M.; Tilanus, H.W.; van Lanschot, J.J.B.; Wijnhoven, B.P. Impact of a multidisciplinary tumour board meeting for upper-GI malignancies on clinical decision making: A prospective cohort study. Int. J. Clin. Oncol. 2013, 18, 214-219. [CrossRef] [PubMed]

12. Pawlik, T.M.; Laheru, D.; Hruban, R.H.; Coleman, J.; Wolfgang, C.L.; Campbell, K.; Ali, S.; Fishman, E.K.; Schulick, R.D.; Herman, J.M.; et al. Evaluating the impact of a single-day multidisciplinary clinic on the management of pancreatic cancer. Ann. Surg. Oncol. 2008, 15, 2081-2088. [CrossRef] [PubMed]

13. Baicus, C.; Rimbas, M.; Baicus, A.; Caraiola, S. Cancer and involuntary weight loss: Failure to validate a prediction score. PLoS ONE 2014, 9, e95286. [CrossRef] [PubMed]

14. Vanderschueren, S.; Geens, E.; Knockaert, D.; Bobbaers, H. The diagnostic spectrum of unintentional weight loss. Eur. J. Intern. Med. 2005, 16, 160-164. [CrossRef] [PubMed]

15. Kuo, Y.H.; Shi, C.S.; Huang, C.Y.; Huang, Y.C.; Chin, C.C. Prognostic significance of unintentional body weight loss in colon cancer patients. Mol. Clin. Oncol. 2018, 8, 539-543. [CrossRef] [PubMed]

16. Fearon, K.C.; Voss, A.C.; Hustead, D.S. Definition of cancer cachexia: Effect of weight loss, reduced food intake, and systemic inflammation on functional status and prognosis. Am. J. Clin. Nutr. 2006, 83, 1345-1350. [CrossRef] [PubMed]

17. Tisdale, M.J. Mechanisms of cancer cachexia. Physiol. Rev. 2009, 89, 381-410. [CrossRef] [PubMed]

18. Cheng, Y.; Wang, N.; Wang, K.; Wang, J.; Tan, B.; Jia, Y.; Dou, Y.; Yu, J. Prognostic value of body mass index for patients undergoing esophagectomy for esophageal squamous cell carcinoma. Jpn. J. Clin. Oncol. 2013, 43, 146-153. [CrossRef]

19. Grotenhuis, B.A.; Wijnhoven, B.P.; Hotte, G.J.; van der Stok, E.P.; Tilanus, H.W.; van Lanschot, J.J. Prognostic value of body mass index on short-term and long-term outcome after resection of esophageal cancer. World J. Surg. 2010, 34, 2621-2627. [CrossRef]

20. Han-Geurts, I.J.; Hop, W.C.; Tran, T.C.; Tilanus, H.W. Nutritional status as a risk factor in esophageal surgery. Dig. Surg. 2006, 23, 159-163. [CrossRef]

21. Watanabe, M.; Ishimoto, T.; Baba, Y.; Nagai, Y.; Yoshida, N.; Yamanaka, T.; Baba, H. Prognostic impact of body mass index in patients with squamous cell carcinoma of the esophagus. Ann. Surg Oncol. 2013, 20, 3984-3991. [CrossRef] [PubMed]

22. Zhang, S.S.; Yang, H.; Luo, K.J.; Huang, Q.Y.; Chen, J.Y.; Yang, F.; Cai, X.L.; Xie, X.; Liu, Q.W.; Bella, A.E.; et al. The impact of body mass index on complication and survival in resected oesophageal cancer: A clinical-based cohort and meta-analysis. Br. J. Cancer 2013, 109, 2894-2903. [CrossRef] [PubMed]

23. Fearon, K.; Arends, J.; Baracos, V. Understanding the mechanisms and treatment options in cancer cachexia. Nat. Rev. Clin. Oncol. 2013, 10, 90-99. [CrossRef] [PubMed]

24. Aoyagi, T.; Terracina, K.P.; Raza, A.; Matsubara, H.; Takabe, K. Cancer cachexia, mechanism and treatment. World J. Gastrointest. Oncol. 2015, 7, 17-29. [CrossRef] [PubMed]

25. Cooper, C.; Burden, S.T.; Cheng, H.; Molassiotis, A. Understanding and managing cancer-related weight loss and anorexia: Insights from a systematic review of qualitative research. J. Cachexia Sarcopenia Muscle 2015, 6, 99-111. [CrossRef] [PubMed]

26. Mattox, T.W. Cancer Cachexia: Cause, Diagnosis, and Treatment. Nutr. Clin. Pract. 2017, 32, 599-606. [CrossRef] [PubMed] 
27. Al-Najim, W.; Docherty, N.G.; le Roux, C.W. Food Intake and Eating Behavior after Bariatric Surgery. Physiol. Rev. 2018, 98, 1113-1141. [CrossRef]

28. Carabotti, M.; Scirocco, A.; Maselli, M.A.; Severi, C. The gut-brain axis: Interactions between enteric microbiota, central and enteric nervous systems. Ann. Gastroenterol. 2015, 28, 203-209.

29. Quigley, E.M.M. The Gut-Brain Axis and the Microbiome: Clues to Pathophysiology and Opportunities for Novel Management Strategies in Irritable Bowel Syndrome (IBS). J. Clin. Med. 2018, 7, 6. [CrossRef]

30. Zhu, X.; Han, Y.; Du, J.; Liu, R.; Jin, K.; Yi, W. Microbiota-gut-brain axis and the central nervous system. Oncotarget 2017, 8, 53829-53838. [CrossRef]

31. Mayer, E.A.; Tillisch, K.; Gupta, A. Gut/brain axis and the microbiota. J. Clin. Investig. 2015, 125, 926-938. [CrossRef] [PubMed]

32. Drucker, D.J.; Nauck, M.A. The incretin system: Glucagon-like peptide-1 receptor agonists and dipeptidyl peptidase-4 inhibitors in type 2 diabetes. Lancet 2006, 368, 1696-1705. [CrossRef]

33. Gunawardene, A.R.; Corfe, B.M.; Staton, C.A. Classification and functions of enteroendocrine cells of the lower gastrointestinal tract. Int. J. Exp. Pathol. 2011, 92, 219-231. [CrossRef] [PubMed]

34. Kim, B.J.; Carlson, O.D.; Jang, H.J.; Elahi, D.; Berry, C.; Egan, J.M. Peptide YY is secreted after oral glucose administration in a gender-specific manner. J. Clin. Endocrinol. Metab. 2005, 90, 6665-6671. [CrossRef] [PubMed]

35. Anini, Y.; Fu-Cheng, X.; Cuber, J.C.; Kervran, A.; Chariot, J.; Roz, C. Comparison of the postprandial release of peptide YY and proglucagon-derived peptides in the rat. Pflug. Arch. Eur. J. Physiol. 1999, 438, 299-306. [CrossRef]

36. Mertens, K.L.; Kalsbeek, A.; Soeters, M.R.; Eggink, H.M. Bile Acid Signaling Pathways from the Enterohepatic Circulation to the Central Nervous System. Front. Neurosci. 2017, 11, 617. [CrossRef] [PubMed]

37. Li, T.; Chiang, J.Y. Bile acid signaling in metabolic disease and drug therapy. Pharmacol. Rev. 2014, 66, 948-983. [CrossRef]

38. Tian, J.; Huang, S.; Sun, S.; Ding, L.; Zhang, E.; Huang, W. Bile acid signaling and bariatric surgery. Liver Res. 2017, 1, 208-213. [CrossRef]

39. Kohli, R.; Myronovych, A.; Tan, B.K.; Salazar-Gonzalez, R.M.; Miles, L.; Zhang, W.; Oehrle, M.; Sandoval, D.A.; Ryan, K.K.; Seeley, R.J.; et al. Bile Acid Signaling: Mechanism for Bariatric Surgery, Cure for NASH? Dig. Dis. 2015, 33, 440-446. [CrossRef]

40. Kimura, I.; Inoue, D.; Hirano, K.; Tsujimoto, G. The SCFA Receptor GPR43 and Energy Metabolism. Front. Endocrinol. 2014, 5, 85. [CrossRef]

41. Inoue, D.; Tsujimoto, G.; Kimura, I. Regulation of Energy Homeostasis by GPR41. Front. Endocrinol. 2014, 5, 81. [CrossRef] [PubMed]

42. Miholic, J.; Meyer, H.J.; Kotzerke, J.; Balks, J.; Aebert, H.; Jahne, J.; Weimann, A.; Pichlmayr, R. Emptying of the gastric substitute after total gastrectomy. Jejunal interposition versus Roux-y esophagojejunostomy. Ann. Surg. 1989, 210, 165-172. [CrossRef] [PubMed]

43. Carswell, K.A.; Vincent, R.P.; Belgaumkar, A.P.; Sherwood, R.A.; Amiel, S.A.; Patel, A.G.; Le Roux, C.W. The effect of bariatric surgery on intestinal absorption and transit time. Obes. Surg. 2014, 24, 796-805. [CrossRef] [PubMed]

44. Olsson, U.; Bosaeus, I.; Svedlund, J.; Bergbom, I. Patients' subjective symptoms, quality of life and intake of food during the recovery period 3 and 12 months after upper gastrointestinal surgery. Eur. J. Cancer Care 2007, 16, 74-85. [CrossRef] [PubMed]

45. Bueter, M.; Lowenstein, C.; Olbers, T.; Wang, M.; Cluny, N.L.; Bloom, S.R.; Sharkey, K.A.; Lutz, T.A.; le Roux, C.W. Gastric bypass increases energy expenditure in rats. Gastroenterology 2010, 138, 1845-1853. [CrossRef] [PubMed]

46. Rhee, N.A.; Wahlgren, C.D.; Pedersen, J.; Mortensen, B.; Langholz, E.; Wandall, E.P.; Friis, S.U.; Vilmann, P.; Paulsen, S.J.; Kristiansen, V.B.; et al. Effect of Roux-en-Y gastric bypass on the distribution and hormone expression of small-intestinal enteroendocrine cells in obese patients with type 2 diabetes. Diabetologia 2015, 58, 2254-2258. [CrossRef] [PubMed]

47. Hansen, C.F.; Bueter, M.; Theis, N.; Lutz, T.; Paulsen, S.; Dalbøge, L.S.; Vrang, N.; Jelsing, J. Hypertrophy dependent doubling of L-cells in Roux-en-Y gastric bypass operated rats. PLoS ONE 2013, 8, e65696. [CrossRef] [PubMed] 
48. Elliott, J.A.; Docherty, N.G.; Eckhardt, H.G.; Doyle, S.L.; Guinan, E.M.; Ravi, N.; Reynolds, J.V.; Roux, C.W. Weight Loss, Satiety, and the Postprandial Gut Hormone Response After Esophagectomy: A Prospective Study. Ann. Surg. 2017, 266, 82-90. [CrossRef]

49. Elliott, J.A.; Jackson, S.; King, S.; McHugh, R.; Docherty, N.G.; Reynolds, J.V.; Le Roux, C.W. Gut Hormone Suppression Increases Food Intake After Esophagectomy With Gastric Conduit Reconstruction. Ann. Surg. 2015, 262, 824-829. [CrossRef]

50. Pournaras, D.J.; Glicksman, C.; Vincent, R.P.; Kuganolipava, S.; Alaghband-Zadeh, J.; Mahon, D.; Bekker, J.H.; Ghatei, M.A.; Bloom, S.R.; Walters, J.R.; et al. The role of bile after Roux-en-Y gastric bypass in promoting weight loss and improving glycaemic control. Endocrinology 2012, 153, 3613-3619. [CrossRef]

51. Tremaroli, V.; Karlsson, F.; Werling, M.; Ståhlman, M.; Kovatcheva-Datchary, P.; Olbers, T.; Fändriks, L.; Le Roux, C.W.; Nielsen, J.; Bäckhed, F. Roux-en-Y Gastric Bypass and Vertical Banded Gastroplasty Induce Long-Term Changes on the Human Gut Microbiome Contributing to Fat Mass Regulation. Cell Metab. 2015, 22, 228-238. [CrossRef] [PubMed]

52. Zheng, S.; Shao, S.; Qiao, Z.; Chen, X.; Piao, C.; Yu, Y.; Gao, F.; Zhang, J.; Du, J. Clinical Parameters and Gut Microbiome Changes Before and After Surgery in Thoracic Aortic Dissection in Patients with Gastrointestinal Complications. Sci. Rep. 2017, 7, 15228. [CrossRef] [PubMed]

53. Lederer, A.K.; Pisarski, P.; Kousoulas, L.; Fichtner-Feigl, S.; Hess, C.; Huber, R. Postoperative changes of the microbiome: Are surgical complications related to the gut flora? A systematic review. BMC Surg. 2017, 17, 125. [CrossRef] [PubMed]

54. Wu, J.T.; Kral, J.G. Ghrelin: Integrative neuroendocrine peptide in health and disease. Ann. Surg. 2004, 239, 464-474. [CrossRef] [PubMed]

55. Date, Y.; Kojima, M.; Hosoda, H.; Sawaguchi, A.; Mondal, M.S.; Suganuma, T.; Matsukura, S.; Kangawa, K.; Nakazato, M. Ghrelin, a novel growth hormone-releasing acylated peptide, is synthesized in a distinct endocrine cell type in the gastrointestinal tracts of rats and humans. Endocrinology 2000, 141, 4255-4261. [CrossRef] [PubMed]

56. Takaya, K.; Ariyasu, H.; Kanamoto, N.; Iwakura, H.; Yoshimoto, A.; Harada, M.; Mori, K.; Komatsu, Y.; Usui, T.; Shimatsu, A.; et al. Ghrelin strongly stimulates growth hormone release in humans. J. Clin. Endocrinol. Metab. 2000, 85, 4908-4911. [CrossRef] [PubMed]

57. Hataya, Y.; Akamizu, T.; Takaya, K.; Kanamoto, N.; Ariyasu, H.; Saijo, M.; Moriyama, K.; Shimatsu, A.; Kojima, M.; Kangawa, K.; et al. A low dose of ghrelin stimulates growth hormone (GH) release synergistically with GH-releasing hormone in humans. J. Clin. Endocrinol. Metab. 2001, 86, 4552. [CrossRef]

58. Wren, A.M.; Small, C.J.; Ward, H.L.; Murphy, K.G.; Dakin, C.L.; Taheri, S.; Kennedy, A.R.; Roberts, G.H.; Morgan, D.G.A.; Ghatei, M.A.; et al. The novel hypothalamic peptide ghrelin stimulates food intake and growth hormone secretion. Endocrinology 2000, 141, 4325-4328. [CrossRef]

59. Schwartz, M.W.; Woods, S.C.; Porte, D.; Seeley, R.J., Jr.; Baskin, D.G. Central nervous system control of food intake. Nature 2000, 404, 661-671. [CrossRef]

60. Takiguchi, S.; Hiura, Y.; Miyazaki, Y.; Takata, A.; Murakami, K.; Doki, Y. Clinical trial of ghrelin synthesis administration for upper GI surgery. Methods Enzymol. 2012, 514, 409-431.

61. Yamamoto, K.; Takiguchi, S.; Miyata, H.; Adachi, S.; Hiura, Y.; Yamasaki, M.; Nakajima, K.; Fujiwara, Y.; Mori, M.; Kangawa, K.; et al. Randomized phase II study of clinical effects of ghrelin after esophagectomy with gastric tube reconstruction. Surgery 2010, 148, 31-38. [CrossRef] [PubMed]

62. Harris, A.M.; Griffin, S.M. Postoperative taste and smell deficit after upper gastrointestinal cancer surgery-An unreported complication. J. Surg. Oncol. 2003, 82, 147-150. [CrossRef] [PubMed]

63. Sonis, S.T. The pathobiology of mucositis. Nat. Rev. Cancer 2004, 4, 277-284. [CrossRef] [PubMed]

64. Bajic, J.E.; Johnston, I.N.; Howarth, G.S.; Hutchinson, M.R. From the Bottom-Up: Chemotherapy and Gut-Brain Axis Dysregulation. Front. Behav. Neurosci. 2018, 12, 104. [CrossRef] [PubMed]

65. Montassier, E.; Gastinne, T.; Vangay, P.; Al-Ghalith, G.A.; Varannes, S.B.D.; Massart, S.; Moreau, P.; Potel, G.; De La Cochetiere, M.F.; Batard, E.; et al. Chemotherapy-driven dysbiosis in the intestinal microbiome. Aliment. Pharmacol. Ther. 2015, 42, 515-528. [CrossRef] [PubMed]

66. Nam, Y.D.; Kim, H.J.; Seo, J.G.; Kang, S.W.; Bae, J.W. Impact of pelvic radiotherapy on gut microbiota of gynecological cancer patients revealed by massive pyrosequencing. PLoS ONE 2013, 8, e82659. [CrossRef] [PubMed] 
67. Touchefeu, Y.; Montassier, E.; Nieman, K.; Gastinne, T.; Potel, G.; Varannes, S.B.D.; Le Vacon, F.; De La Cochetiere, M.F. Systematic review: The role of the gut microbiota in chemotherapy-or radiation-induced gastrointestinal mucositis-Current evidence and potential clinical applications. Aliment. Pharmacol. Ther. 2014, 40, 409-421. [CrossRef] [PubMed]

68. Kumagai, T.; Rahman, F.; Smith, A.M. The Microbiome and Radiation Induced-Bowel Injury: Evidence for Potential Mechanistic Role in Disease Pathogenesis. Nutrients 2018, 10, 1405. [CrossRef]

69. Grimberg, A. Somatostatin and cancer: Applying endocrinology to oncology. Cancer Biol. Ther. 2004, 3, 731-733. [CrossRef] [PubMed]

70. Li, S.-C.; Martijn, C.; Cui, T.; Essaghir, A.; Luque, R.M.; Demoulin, J.-B.; Castaño, J.P.; Öberg, K.; Giandomenico, V. The somatostatin analogue octreotide inhibits growth of small intestine neuroendocrine tumour cells. PLoS ONE 2012, 7, e48411. [CrossRef] [PubMed]

71. Elliott, J.A.; Docherty, N.G.; Haag, J.; Eckhardt, H.G.; Ravi, N.; Reynolds, J.V.; Le Roux, C.W. Attenuation of satiety gut hormones increases appetitive behavior after curative esophagectomy for esophageal cancer. Am. J. Clin. Nutr. 2019, 109, 335-344. [CrossRef] [PubMed]

72. Oberg, K.; Lamberts, S.W. Somatostatin analogues in acromegaly and gastroenteropancreatic neuroendocrine tumours: Past, present and future. Endocr. Relat. Cancer 2016, 23, R551-R566. [CrossRef] [PubMed]

73. Vecht, J.; Lamers, C.B.; Masclee, A.A. Long-term results of octreotide-therapy in severe dumping syndrome. Clin. Endocrinol. (Oxf.) 1999, 51, 619-624. [CrossRef] [PubMed]

74. Geer, R.J.; Richards, W.O.; O'dorisio, T.M.; Woltering, E.O.; Williams, S.; Rice, D.; Abumrad, N.N. Efficacy of octreotide acetate in treatment of severe postgastrectomy dumping syndrome. Ann. Surg. 1990, 212, 678-687. [CrossRef] [PubMed]

75. Ahrendt, S.A.; McGuire, G.E.; Pitt, H.A.; Lillemoe, K.D. Why does somatostatin cause gallstones? Am. J. Surg. 1991, 161, 177-182. [CrossRef]

76. Redfern, J.S.; Fortuner, W.J., 2nd. Octreotide-associated biliary tract dysfunction and gallstone formation: Pathophysiology and management. Am. J. Gastroenterol. 1995, 90, 1042-1452. [PubMed]

77. García, J.M.; Boccia, R.V.; Graham, C.D.; Yan, Y.; Duus, E.M.; Allen, S.; Friend, J. Anamorelin for patients with cancer cachexia: An integrated analysis of two phase 2, randomised, placebo-controlled, double-blind trials. Lancet Oncol. 2015, 16, 108-116. [CrossRef]

78. Garcia, J.M.; Friend, J.; Allen, S. Therapeutic potential of anamorelin, a novel, oral ghrelin mimetic, in patients with cancer-related cachexia: A multicenter, randomized, double-blind, crossover, pilot study. Supportive Care Cancer 2013, 21, 129-137. [CrossRef] [PubMed]

79. Takayama, K.; Katakami, N.; Yokoyama, T.; Atagi, S.; Yoshimori, K.; Kagamu, H.; Saito, H.; Takiguchi, Y.; Aoe, K.; Koyama, A.; et al. Anamorelin (ONO-7643) in Japanese patients with non-small cell lung cancer and cachexia: Results of a randomized phase 2 trial. Supportive Care Cancer 2016, 24, 3495-3505. [CrossRef]

80. Zhang, H.; Garcia, J.M. Anamorelin hydrochloride for the treatment of cancer-anorexia-cachexia in NSCLC. Expert Opin. Pharm. 2015, 16, 1245-1253. [CrossRef]

81. Elliott, J.A.; Reynolds, J.V.; le Roux, C.W.; Docherty, N.G. Physiology, pathophysiology and therapeutic implications of enteroendocrine control of food intake. Expert Rev. Endocrinol. Metab. 2016, 11, 475-499. [CrossRef] [PubMed]

82. Hendifar, A.E.; Petzel, M.Q.B.; Zimmers, T.A.; Denlinger, C.S.; Matrisian, L.M.; Picozzi, V.J.; Rahib, L. Pancreas Cancer-Associated Weight Loss. Oncologist 2019, 24, 691-701. [CrossRef]

83. Halem, H.A.; Taylor, J.E.; Dong, J.Z.; Shen, Y.; Datta, R.; Abizaid, A.; Diano, S.; Horvath, T.; Zizzari, P.; Bluet-Pajot, M.T.; et al. Novel analogs of ghrelin: Physiological and clinical implications. Eur. J. Endocrinol. 2004, 151 (Suppl. 1), S71-S75. [CrossRef] [PubMed]

84. Rhodes, L.; Zollers, B.; Wofford, J.A.; Heinen, E. Capromorelin: A ghrelin receptor agonist and novel therapy for stimulation of appetite in dogs. Vet. Med. Sci. 2018, 4, 3-16. [CrossRef] [PubMed]

85. Reim, D.; Friess, H. Feeding Challenges in Patients with Esophageal and Gastroesophageal Cancers. Gastrointest. Tumors 2016, 2, 166-177. [CrossRef] [PubMed]

86. Rosania, R.; Chiapponi, C.; Malfertheiner, P.; Venerito, M. Nutrition in Patients with Gastric Cancer: An Update. Gastrointest. Tumors 2016, 2, 178-187. [CrossRef] [PubMed]

87. Ichim, T.E.; Kesari, S.; Shafer, K. Protection from chemotherapy- and antibiotic-mediated dysbiosis of the gut microbiota by a probiotic with digestive enzymes supplement. Oncotarget 2018, 9, 30919-30935. [CrossRef]

88. Delgado, T.C. Glutamate and GABA in Appetite Regulation. Front. Endocrinol. 2013, 4, 103. [CrossRef] 
89. Krashes, M.J.; Shah, B.P.; Koda, S.; Lowell, B.B. Rapid versus delayed stimulation of feeding by the endogenously released AgRP neuron mediators GABA, NPY, and AgRP. Cell Metab. 2013, 18, 588-595. [CrossRef]

90. Elinav, E.; Niv-Spector, L.; Katz, M.; Price, T.O.; Ali, M.; Yacobovitz, M.; Solomon, G.; Reicher, S.; Lynch, J.L.; Halpern, Z.; et al. Pegylated leptin antagonist is a potent orexigenic agent: Preparation and mechanism of activity. Endocrinology 2009, 150, 3083-3091. [CrossRef]

91. Ottaway, N.; Mahbod, P.; Rivero, B.; Norman, L.A.; Gertler, A.; D’Alessio, D.A.; Perez-Tilve, D. Diet-induced obese mice retain endogenous leptin action. Cell Metab. 2015, 21, 877-882. [CrossRef] [PubMed]

92. Levi, J.; Gray, S.L.; Speck, M.; Huynh, F.K.; Babich, S.L.; Gibson, W.T.; Kieffer, T.J. Acute disruption of leptin signaling in vivo leads to increased insulin levels and insulin resistance. Endocrinology 2011, 152, 3385-3395. [CrossRef] [PubMed]

93. Foster, A.C.; Chen, C.; Markison, S.; Marks, D.L. MC4 receptor antagonists: A potential treatment for cachexia. Idrugs Investig. Drugs J. 2005, 8, 314-319.

94. Foster, A.C.; Chen, C. Melanocortin-4 receptor antagonists as potential therapeutics in the treatment of cachexia. Curr. Top. Med. Chem. 2007, 7, 1131-1136. [CrossRef] [PubMed]

95. Dallmann, R.; Weyermann, P.; Anklin, C.; Boroff, M.; Bray-French, K.; Cardel, B.; Courdier-Fruh, I.; Deppe, H.; Dubach-Powell, J.; Erb, M.; et al. The orally active melanocortin-4 receptor antagonist BL-6020/979: A promising candidate for the treatment of cancer cachexia. J. Cachexiasarcopenia Muscle 2011, 2, 163-174. [CrossRef] [PubMed]

96. Gupta, S.; Allen-Vercoe, E.; Petrof, E.O. Fecal microbiota transplantation: In perspective. Ther. Adv. Gastroenterol. 2016, 9, 229-239. [CrossRef] [PubMed]

97. Jeon, S.R.; Chai, J.; Kim, C.; Lee, C.H. Current Evidence for the Management of Inflammatory Bowel Diseases Using Fecal Microbiota Transplantation. Curr. Infect. Dis. Rep. 2018, 20, 21. [CrossRef] [PubMed]

98. Sunkara, T.; Rawla, P.; Ofosu, A.; Gaduputi, V. Fecal microbiota transplant-A new frontier in inflammatory bowel disease. J. Inflamm. Res. 2018, 11, 321-328. [CrossRef] [PubMed]

99. Pinn, D.M.; Aroniadis, O.C.; Brandt, L.J. Is fecal microbiota transplantation (FMT) an effective treatment for patients with functional gastrointestinal disorders (FGID)? Neurogastroenterol. Motil. 2015, 27, 19-29. [CrossRef] [PubMed]

100. De Groot, P.F.; Frissen, M.N.; de Clercq, N.C.; Nieuwdorp, M. Fecal microbiota transplantation in metabolic syndrome: History, present and future. Gut Microbes 2017, 8, 253-267. [CrossRef] [PubMed]

101. Woodworth, M.H.; Carpentieri, C.; Sitchenko, K.L.; Kraft, C.S. Challenges in fecal donor selection and screening for fecal microbiota transplantation: A review. Gut Microbes 2017, 8, 225-237. [CrossRef] [PubMed]

102. Alang, N.; Kelly, C.R. Weight gain after fecal microbiota transplantation. Open Forum Infect. Dis. 2015, 2, ofv004. [CrossRef] [PubMed]

103. Ridaura, V.K.; Faith, J.J.; Rey, F.E.; Cheng, J.; Duncan, A.E.; Kau, A.L.; Griffin, N.W.; Lombard, V.; Henrissat, B.; Bain, J.R.; et al. Gut microbiota from twins discordant for obesity modulate metabolism in mice. Science 2013, 341, 1241214. [CrossRef] [PubMed]

(C) 2019 by the authors. Licensee MDPI, Basel, Switzerland. This article is an open access article distributed under the terms and conditions of the Creative Commons Attribution (CC BY) license (http://creativecommons.org/licenses/by/4.0/). 